Research Article

\title{
Snodgrass tubularized incised plate urethroplasty for distal penile hypospadias in paediatric age group: our experience
}

\author{
Ajay Kumar Jain*, Dhiraj Sharma, Kailash Charokar
}

Department of Surgery, PCMS \& RC, Bhopal, MP, India

Received: 04 November 2015

Revised: 06 November 2015

Accepted: 12 December 2015

\section{*Correspondence:}

Dr. Ajay Kumar Jain,

E-mail: 123ajayjain@gmail.com

Copyright: ( $)$ the author(s), publisher and licensee Medip Academy. This is an open-access article distributed under the terms of the Creative Commons Attribution Non-Commercial License, which permits unrestricted non-commercial use, distribution, and reproduction in any medium, provided the original work is properly cited.

\section{ABSTRACT}

Background: To report short term results of Snodgrass tubularized incised plate (TIP) urethroplasty in distal penile hypospadias (DPH) repair. The complications and outcomes of the procedure are discussed.

Methods: We reviewed the results of 30 cases of Snodgrass TIP urethroplasty for distal penile hypospadias (DPH) treated between November 2003 and April 2005 in paediatric patients. Observations were recorded to note the associated anomalies, cosmesis, complications and final outcome of the procedure.

Results: The age of the study participants ranged from 2 to 12 years. About half $(52 \%)$ of the cases presented early below 5 years of age and barely few (12\%) reported late after 10 years of age. Meatal configuration, overall cosmesis and functional results were good in 26 cases (86\%). Minor fistulas occurred in 5 cases whereas major fistula occurred in 2 cases (7\%). Overall complications rate, requiring specific intervention was 2 cases $(7 \%)$.

Conclusions: In our experience, Snodgrass TIP urethroplasty is technically simple, easy to learn, single stage procedure with excellent functional and cosmetic outcomes for DPH. It has simplified the algorithm for distal penile hypospadias.

Keywords: Distal penile hypospadias, Urethroplasty, Tubularized incised plate urethroplasty, Snodgrass TIP urethroplasty

\section{INTRODUCTION}

Hypospadias (in Greek, hypo means "under" and spadon, means "rent") is a congenital defect of the penis with incomplete development of the anterior urethra resulting in meatus opening on under surface proximal to the tip of glans. It is one of the most common congenital anomaly of male genital system associated with significant physical and psychological trauma not only to the affected child but to the parents as well. In India, about 75,000 children are born every year with hypospadias, distal penile hypospadias (DPH) accounting for about 80 $85 \%$ of these cases. ${ }^{1}$
Reconstructing a functioning phallus that allows a boy to void as a "pointer" instead of a "squatter" and later to become a sexually active can be one of the most gratifying moments for the operating surgeon. Since the first descriptions of attempted surgical repair in 1874 , more than 200 different surgical operations have been described to correct the defect. ${ }^{2}$ Initial corrective attempts were frequently associated with fistula formation or poor cosmesis (horizontal meatus), requiring staged procedures.

Snodgrass introduced the concept of tubularized incised plate (TIP) urethroplasty repair with excellent short-term results and cosmesis almost replacing all other hypospadias repair and simplifying decision making. The 
present study explores the outcome of distal penile hypospadias (DPH) repair using TIP urethroplasty as described by Snodgrass, which gives excellent functional and cosmetic results. All children undergoing surgical correction of distal penile hypospadias with TIP urethroplasty were included in the study.

\section{METHODS}

This is a prospective observational study carried out at a medical college hospital of Bhopal, Madhya Pradesh, India. All children in the age group of 2-12 years presenting to the surgical out-patient department with distal penile hypospadias from November 2003 to April 2005 were included in the study. A total of 66 patients of hypospadias were evaluated of which 30 were having distal penile hypospadias. All 30 cases of DPH underwent correction with Snodgrass TIP urethroplasty and were included in the study. Cases with previous urethroplasty were excluded from the study. After detailed history and physical examination, all subjects underwent laboratory investigations and pre-anesthetic checkups as part of routine preoperative work up. Observations were recorded to note the complications, failure, cosmetics, need for repeat surgery and final outcome of the procedure. Operative procedure; The TIP urethroplasty technique was used in all cases as described by Snodgrass. A circumscribing skin incision was made 2 $\mathrm{mm}$ proximal to the meatus. The penile skin was degloved down to the penoscrotal junction. Full tuminescence of the corpora cavernosa was achieved using normal saline, to simulate penile erection for assessing chordee and curvature of penis. The urethral plate was tubularized over a 7-8 Fr feeding tube catheter (depending on the child's age) with a continuous 6-0 PDS absorbable suture to create the neourethra. The glandular wings were approximated by a 6-0 vicryl absorbable suture, and the distal ends were fixed to the underlying neourethra at 5 and 7 o'clock with the same type of suture. After the completion of repair, a urethral stent was fixed to the glans penis with a $3 / 0$ silk suture and the catheter was left for 7-10 days postoperatively. A slitlike, vertically oriented meatus and a conical glanular shape with a good forward urinary stream were the criteria for good results. Observations were recorded to note the associated anomalies, cosmesis, complications and final outcome of the procedure.

\section{RESULTS}

A total of 66 cases of hypospadias were included in the study out of which only 30 cases underwent repair by TIP urethroplasty method. The age of the study participants ranged from 2 to 12 years. About half $(52 \%)$ of the cases presented early below 5 years of age and barely few $(12 \%)$ reported late after 10 years of age.

All cases were carefully looked for associated congenital anomalies (Table 1).
Table 1: Showing distribution of associated congenital anomalies $(\mathrm{N}=66)$.

\begin{tabular}{|lll|}
\hline $\begin{array}{l}\text { Associated congenital } \\
\text { anomalies }\end{array}$ & No. of cases & Percentage \\
\hline Inguinal hernia & 4 & 06 \\
\hline Undescended testis & 2 & 03 \\
\hline VSD & 2 & 03 \\
\hline Intersex & 1 & 01 \\
\hline $\begin{array}{l}\text { No associated } \\
\text { congenital anomaly }\end{array}$ & 57 & 87 \\
\hline
\end{tabular}

The short term results of TIP urethroplasty were analyzed on the basis of cosmetic and functional outcome as well as the complications (Table 2).

\section{Table 2: Showing distribution of overall outcome of TIP urethroplasty $(\mathrm{N}=30)$.}

\begin{tabular}{|c|c|c|c|}
\hline \multicolumn{2}{|c|}{ Surgical outcome measured } & $\begin{array}{l}\text { No. of } \\
\text { cases }\end{array}$ & \multirow{2}{*}{$\begin{array}{l}\text { Percentage } \\
(\%) \\
86\end{array}$} \\
\hline \multirow{3}{*}{$\begin{array}{l}\text { Meatal } \\
\text { configuration }\end{array}$} & Vertical slit like & 26 & \\
\hline & Circular & 2 & 7 \\
\hline & Stenotic & 2 & 7 \\
\hline \multirow{2}{*}{$\begin{array}{l}\text { Meatal } \\
\text { location }\end{array}$} & At tip of glans & 30 & 100 \\
\hline & Other & Nil & - \\
\hline \multirow{3}{*}{$\begin{array}{l}\text { Overall } \\
\text { cosmesis }\end{array}$} & Excellent & 26 & 86 \\
\hline & Average & 2 & 7 \\
\hline & Poor & 2 & 7 \\
\hline \multirow{2}{*}{$\begin{array}{l}\text { Shape of } \\
\text { glans }\end{array}$} & Conical & 30 & 100 \\
\hline & Other & Nil & - \\
\hline \multirow{3}{*}{ Function } & $\begin{array}{l}\text { Good, strong, } \\
\text { forward stream }\end{array}$ & 26 & 86 \\
\hline & $\begin{array}{l}\text { thin, forward } \\
\text { stream }\end{array}$ & 2 & 7 \\
\hline & $\begin{array}{l}\text { Poor stream with } \\
\text { spraying }\end{array}$ & 2 & 7 \\
\hline \multirow{2}{*}{ Fistula } & Minor & 5 & 17 \\
\hline & Major & 2 & 7 \\
\hline
\end{tabular}

\section{DISCUSSION}

Snodgrass TIP urethroplasty has become procedure of the choice for DPH in modern era. Most of the cases of DPH are either without chordee or with skin chordee which is relieved by degloving of penile skin.

Hypospadias is one of the common congenital anomaly. It is associated with other anomalies as well. The most common anomalies associated with hypospadias are undescended testes and inguinal hernia. We observed inguinal hernia (8 cases) and undescended testes (4 cases) with hypospadias. Khuri and co-workers (1981) found a $9 \%$ incidence of undescended testes in patients with hypospadias. They also noted that the incidence of inguinal hernia was $9 \%$ in the total group. ${ }^{3}$ Ventricular septal defect (2 cases) and intersex (1 case) were other anomalies noted in our study. 
The primary objective of all hypospadias repair is to attain a functional neo-urethra with a near normal appearing penis. The repair of hypospadias has been a challenge to the surgeons for over a century. In 1994, a new method for distal hypospadias repair was described in which tubularization of the urethral plate without skin flaps was facilitated by midline plate incision. It was noted subsequently that the tubularized incised plate (TIP) technique simplified decision making in distal hypospadias surgery because the operation was successful regardless of various meatal and urethral plate configurations encountered by Snodgrass. ${ }^{4,5}$

The TIP urethroplasty is currently a popular technique for hypospadias repair. ${ }^{6,7}$ The midline incision renders a narrow and shallow urethral plate wide enough for easy tubularization. Moreover, it provides a vertically oriented and cosmetically normal neo-meatus. ${ }^{5,7}$ The urethral plate is divided into two epithelial strips that are approximated ventrally to form the floor of neourethra, while the roof and sometimes the side walls are formed by the increased raw area that heals by re-epithelialization of relaxing incision without obvious scarring allowing the incised edges to remain separated..$^{8-12}$

All cases have good cosmetic appearance at the time of discharge and follow up which match with other reported studies. $^{5,7,13}$ Meatal configurations was noted to be vertical slit like in 26 cases $(87 \%)$ of our series which has been stated to be one of the main advantage of TIP urethroplasty. Others have reported similar results. $5,7,14,15$ In two patients with infection, the final appearance was circular while other two developed meatal stenosis as a result of relaxing incision extending beyond urethral plate. In the study conducted by Zhou Y et al meatal stenosis was noted in $4 \%$ of cases which are comparable. ${ }^{10}$ Our results compare favourably with other studies. $5,16,17,18$

Fistula formation was seen in 7 cases (24\%) of which 5 were minor and two major. In a literature review of 54 case series, the median fistula rate was $5 \%$ (mean = $5.9 \%$ ), ranging from 0 to $16 \% .^{19-21}$ The 5 minor cases responded to regular urethra dilations. The two major fistulas required reoperation. The possible reasons for high fistula rate in our study could be catheter related as we used PVC feeding tube. PVC feeding tube causes irritation and desquamation of the cells from neourethra with resultant blockage of the already small eye of the catheter. The 5 cases which developed fistula in our study had blocked catheters.

All patients had meatus at the tip of conical glans. None of the patient had glandular dehiscence. Other series have also reported similar results. ${ }^{5,7,13-15}$

The overall cosmetic results were excellent $(87 \%)$ in our study with appearance similar to circumcised penis, conical glans and vertical slit like meatus. The two patients with flap necrosis had poor cosmesis while two patients with wound infection had average cosmesis. Our results are comparable to other reported series. ${ }^{5,7,14,15}$ The shape of the glans was conical in all the cases. This is another advantage of TIP urethroplasty. Others have reported similar results. $5,7,14,15$

The two cases of meatal stenosis $(7 \%)$ had thin stream while two $(7 \%)$ cases with flap necrosis developed fistula at corona leading to spraying of urine. Other authors have reported similar complication rate from $0-16 \% .^{19-21}$

Good solid forward stream of urine was noted in almost all $(87 \%)$ cases of TIP urethroplasty. Our findings are similar to other authors. $5,13,16-18,22,23$

All study subjects were followed for a period of 18 months and none reported to have penile torsion or stricture. Others also had similar observations. ${ }^{5,7,14,15}$

It has been reported that smaller series usually have higher complications due to initial learning curve. However, in later parts of the studies, complication rates come down significantly as happened in our series too. ${ }^{24}$

\section{CONCLUSION}

In our experience, Snodgrass TIP urethroplasty is technically simple, easy to learn, single stage procedure with excellent functional and cosmetic outcomes for DPH. It has simplified the algorithm for distal penile hypospadias.

Funding: No funding sources

Conflict of interest: None declared

Ethical approval: The study was approved by the institutional ethics committee

\section{REFERENCES}

1. Sweet RA, Schortt HG, Kurland R, Culp OS. Study of the incidence of hypospadias in Rochester, Minnesota, 1940-70, and a case control comparison of possible etiologic factors. Mayo Clin Proc. 1974;49:52-8.

2. Duckett JW. Hypospadias. Pediatr Rev. 1989;11:3744.

3. Khuri FJ, Hardy BE, Churchill BM. Urologic anomalies associated with hypospadias. Urol Clin North Am. 1981;8:565-71.

4. Snodgrass W. Changing concepts in hypospadias repair. Curr Opin Urol. 1999;9:513-6.

5. Snodgrass WT. Incised plate urethroplasty for distal hypospadias. J Urol. 1994;151:464-5.

6. Elbakry A. Incised urethral plate urethroplasty: Is regular dilatation necessary for success? BJU Int. 1999;84:683-6.

7. Snodgrass W, Koyle M, Manzoni G, Hurwitz R, Caldamone A, Ehrlich R. Tubularized incised plate hypospadias repair for proximal hypospadias. J Urol. 1998;159:2129-3. 
8. Rich MA, Keating MA, Snyder H, Mc C III, Duckett JW. Hinging the urethral plate in hypospadias meatoplasty. J Urol. 1989:142:1551-3.

9. Bhaumik K, Goswami SM, Konar HL, Basu KS, Das S, Mukherji P, et al. Our experience with Tubularised Incised Plate Urethroplasty in Various Types of Hypospadias, J Indian Assoc Pediatr Surg. 2003;8:108-12.

10. Zhou Y, J Lu, Takarashi G. Snodgrass procedure for primary hypospadias repair. J Urol. 2002;9:215-8.

11. Al-Hunayan AA, Kehinde EO, Elsalam MA, AlMukhtar RS. Tubularized incised plate uretheroplasty: modification and outcome. Int Urol Nephrol. 2003;35:47-52.

12. Bleustein CB, Esposito MP, Soslow RA. Mechanism of healing following the Snodgrass repair. J Urol. 2001:165:277-9.

13. Roy SJS, Saha K, Bhattacharjee PK, Majhi TK. Short Term Results of Snodrass Tubularized Incised plate urethroplasty in distal and mid penile hypospadias, J. Indian Assoc. Pediatr. Surg. 2003;8:226-30.

14. Belman AB. De-Epithelialized skin flap coverage in hypospadias repair. J Urol. 1988;140:1273-6.

15. Retik AB, Mandell J, Bauer SB, Atala A. Meatal based hypospadias repair with the use of dorsal subcutaneous flap to prevent urethrocutaneous fistula. J Urol. 1994;152:1229-31.

16. Oswald J, Korner I, Riccabona M. Comparison of Peri meatal based flap (Mathieu) and the tubularized incised - plate urethroplasty (Snodgrass) in primary distal hypospadias. BJU Int. 2000;85:725-7.
17. Dayane M, Tan MO, Gokalp A. Tubularized incised - plate urethroplasty for distal and mid-penile hypospadias. Eur Urol. 2000;37:102-5.

18. Snodgrass W, Koyle M, Manzoni G. Tubularized incised plate hypospadias repair: results of a multicenter experience. J Urol. 1996;156:839-41.

19. Imamoglu MA, Bakirtas H. Comparison of two methods -Mathieu and Snodgrass - in hypospadias repair. Urol Int. 2003;71:251-4.

20. Anwar-ul-haq, Akhter N, Nilofer, Samiullah, Javeria Comparative study of Mathieu and Snodgrass repair for anterior hypospadias. J Ayub Med Coll Abbottabad. 2006;18:50-2.

21. Guo Y, Ma G, Ge Z. Comparison of the Mathieu and the Snodgrass urethroplasty in distal hypospadias repair. Nat J Androl. 2004;10:916-8.

22. Snodgrass WT, Lorenzo A. Tubularized incised plate urethroplasty for proximal hypospadias. BJU Int. 2002;89:90-3.

23. Sugarman ID, Trevett J, Malone PS. Tubularization of the incised urethral plate (Snodgrass procedure) for primary hypospadias surgery. BJU Int. 1999;83:88-90.

24. Duplay S. On the surgical treatment of hypospadias in pispadias. Arch Gen Med. 1880:145-9.

Cite this article as: Jain AK, Sharma D, Charokar K. Snodgrass tubularized incised plate urethroplasty for distal penile hypospadias in paediatric age group: our experience. Int Surg J 2016;3:217-20. 